\title{
Erratum to: Effect of the CNT Content on Microstructure, Physical and Mechanical Properties of Cu-Based Electrical Contact Materials Produced by Flake Powder Metallurgy
}

\author{
T. Varol ${ }^{1}$ - A. Canakci ${ }^{1}$
}

Published online: 10 December 2015

(C) King Fahd University of Petroleum \& Minerals 2015

\section{Erratum to: Arab J Sci Eng}

DOI 10.1007/s13369-015-1734-6

The original version of this article unfortunately contained a mistake. The name of the first author T. Varol was incorrectly given as T. Varo in the HTML version of this article.

The online version of the original article can be found under doi:10.1007/s13369-015-1734-6.

$\triangle$ A. Canakci

aykut@ktu.edu.tr

1 Department of Metallurgical and Materials Engineering, Engineering Faculty, Karadeniz Technical University,

Trabzon, Turkey 